\title{
MACHADO DE ASSIS E MONTE ALVERNE
}

José Américo Miranda

(UFMG/CNPq/FAPES)

\section{RESUMO}

Este artigo aborda o poema "Monte Alverne", de Machado de Assis, e apresenta possíveis razões para sua exclusão das Poesias completas organizadas pelo próprio poeta em 1901. Na busca por explicações para a exclusão, o poema foi examinado nas relações com o contexto de sua produção, em suas imagens e em aspectos técnicos de sua versificação.

PALAVRAS-CHAVE: Poesia brasileira; Machado de Assis; Monte Alverne.

Machado de Assis, quando publicou Crisálidas, seu primeiro livro de poesias, em 1864, reuniu nele tanto poemas inéditos como poemas que já havia divulgado na imprensa periódica. Um dos críticos da obra fez-lhe restrições ao título, precisamente "porque as produções reunidas em um feixe [no livro] despossuem o mérito da novidade" (LEITÃO, 1866, p. 380). Entre os poemas já divulgados e conhecidos, o mais antigo que apareceu no livro foi "Monte Alverne", redigido e publicado em 1858 (SOUSA, 1955, p. 319; MAGALHÃES JÚNIOR, 1981, v. 1, p. 50).

Quando preparou, em 1901, a edição de suas Poesias completas, o poeta excluiu dezessete dos 29 poemas que existiam na primeira edição. Dos dezessete poemas excluídos, dezesseis eram de sua autoria, e um era de Faustino Xavier de Novais. Além disso, pequeno fragmento dos "Versos a Corina" foi, também, eliminado. Se esse fragmento for levado em consideração, o total de exclusões chega a dezoito. De seus outros livros de poesias, Machado de Assis também fez exclusões; porém, Crisálidas foi o livro de que ele mais suprimiu poemas. 
$\mathrm{Na}$ "Advertência" às Poesias completas, escreveu o autor: "Suprimo da primeira série [isto é, dos três primeiros livros - Crisálidas, $\mathrm{Fa}$ lenas e Americanas] algumas páginas; as restantes bastam para notar a diferença de idade e de composição" (ASSIS, 1901, p. V). Essas palavras supõem um leitor interessado na evolução da poesia de Machado de Assis ao longo do tempo: amostras dos primeiros versos poderiam, no volume de 1901, ser comparadas com amostras de versos escritos em outros tempos - e assim o leitor faria sua própria avaliação.

As supressões de poemas não ocorreram isoladamente; além delas, o poeta reorganizou os poemas dentro do livro, certamente guiado pelo senso apurado que possuía da forma. Parece não haver dúvidas de que Machado de Assis procurou dar maior unidade a seu primeiro livro (assim como a parte do segundo). Do segundo volume de versos, Falenas, obra dividida em quatro partes, Machado de Assis suprimiu poemas, nas Poesias completas, apenas da primeira parte, embora tenha, também, reorganizado a disposição dos poemas na segunda parte - "Lira chinesa" (ASSIS, 1870, p. 9-126; ASSIS, 1901, p. 53-99).

Haveria duas ordens de razões para explicar a escolha dos poemas a excluir: em primeiro lugar, há o aspecto positivo, que determinaria a exclusão de um poema não por problemas que lhe fossem internos, mas, simplesmente, porque ele não contribuiria para o equilíbrio e a forma final do livro; em segundo, há o aspecto negativo, que faria com que um poema fosse excluído do livro por parecer, em si mesmo, insatisfatório ao poeta maduro.

Outro ponto a ser considerado é o da relação do poeta com a crítica de seu tempo. Diversos críticos fizeram restrições, quando do tempo do aparecimento de Crisálidas (1864), a alguns dos poemas do livro. Tendo sido crítico literário o próprio Machado de Assis, e, se considerarmos seu pensamento, externado em 1865, de que a crítica deveria ser um "farol seguro" para as musas, e de que, numa crítica ideal, "o conselho substituiria a intolerância", não resta dúvida sobre o papel do crítico perante o poeta: seria ele um orientador, um conhecedor da "matéria em que fala"; e caberia ao poeta acatar como "estímulo" a orientação da crítica (ASSIS, 1955a, p. 11-19).

Se, como crítico, julgava ele assim, seria de se esperar que, como poeta, por coerência e retidão, assumisse, perante seus críticos, a mesma atitude que esperava dos que criticava. Essa não é uma consideração que se deva desprezar, ao avaliar a parte da obra poética da juventude que o próprio autor "renegou" na maturidade. 
Confirma esse argumento a "Advertência" que Machado de Assis antepôs ao texto de seu primeiro romance, Ressureição, publicado em 1872. Nela, ele avisa ser o livro um "ensaio", que público e crítica haveriam de julgar; e, depois de um parágrafo consistente sobre a usual modéstia afetada dos prólogos, nega que sua "Advertência" tenha qualquer semelhança com eles:

Venho apresentar-lhe ["à crítica boa e sisuda"] um ensaio em gênero novo para mim, e desejo saber se alguma qualidade me chama para ele, ou todas me faltam, - em cujo caso, como em outro campo já tenho trabalhado com alguma aprovação, a ele volverei cuidados e esforços. O que eu peço à crítica vem a ser - intenção benévola, mas expressão franca e justa. Aplausos, quando os não fundamenta o mérito, afagam certamente o espírito, e dão algum verniz de celebridade; mas quem tem vontade de aprender e quer fazer alguma coisa, prefere a lição que melhora ao ruído que lisonjeia. (ASSIS, 1955c, p. 7-8.)

Como se vê, é possível reconhecer que, quando criticado, sua perspectiva, no tocante à relação entre crítico e poeta, não era diferente da que adotava no exercício da crítica - ainda que em seu texto houvesse algo da modéstia afetada que ele negava ter, e ainda que se possa entender essa mesma negativa como parte dela.

Os poemas excluídos pelo poeta foram reintroduzidos nas Poesias completas, em seção que se seguia ao conjunto de poemas por ele conservados na obra, a partir de 1937, quando a Editora W. M. Jackson, tendo adquirido o direito de "propriedade literária", deu início à publicação das obras completas do escritor.

No que diz respeito a Crisálidas, conforme constatou Galante de Sousa, embora os editores afirmassem haver incluído no livro "as peças que o autor rejeitou", ficaram faltando os seguintes sete poemas: "Lúcia", "Fé", "A caridade", "A jovem cativa", "Aspiração", "As Ondinas" e "Cleópatra". Esses poemas só retornaram, de fato, ao livro, na quinta edição dessa casa editora, em 1953 (SOUSA, 1955, p. 100-105; ASSIS, 1937, p. 7-82; ASSIS, 1953, p. 5-104). Os nove poemas reintroduzidos no livro nas quatro primeiras edições W. M. Jackson já não se encontravam na ordem em que apareciam na primeira edição de Crisálidas. Com o acréscimo, em 1953, dos sete que estavam faltando, a desordem tornou-se ainda maior.

Essa ordem foi respeitada, entretanto, conservando do mesmo modo os poemas rejeitados em seção distinta da dos poemas que o autor 
deixou no livro em 1901, na edição crítica das Poesias completas, de 1976 (ASSIS, 1976, p. 117).

Os poemas que retornaram ao livro em 1937 são os seguintes: "O dilúvio", "No limiar", "Os arlequins", "As rosas", "Os dous horizontes", "Monte Alverne", "As ventoinhas", "Maria Duplessis" e "Alpujarra". O pequeno trecho dos "Versos a Corina", eliminado em 1901, voltou ao livro, na seção dos versos constantes apenas da primeira edição, como os sete já mencionados anteriormente, em 1953.

\section{1}

De todos os poemas suprimidos de Crisálidas, o que mais acumula dados contra si é "Monte Alverne". Machado de Assis, desde sua estreia, em outubro de 1854 (SOUSA, 1979, p. 17), até 1863, ano anterior à publicação do primeiro livro de versos, escrevera e, em sua quase totalidade, publicara em periódicos, salvo engano de nossa parte, e sem considerar poemas recentemente descobertos (COZER, 2015; MORAES, 2007), 92 poesias - três delas, pelo menos, perdidas. Dessas 92, apenas 21 foram incluídas no livro - nem todas, diga-se, publicadas antes na imprensa periódica (SOUSA, 1955, p. 305-381).

A mais antiga das composições que apareceu no livro de versos foi, justamente, "Monte Alverne", publicada originalmente em 6 de dezembro de 1858, como "Publicação a pedido", no Suplemento do Jornal do Comércio, apenas quatro dias após a morte do orador (MAGALHÃES JÚNIOR, 1981 v. 1, p. 50; ASSIS, 1858, p. 6). A segunda composição mais antiga incluída em Crisálidas foi "Maria Duplessis", tradução de Alexandre Dumas Filho, única das poesias compostas em 1859 incluída no volume, com primeira publicação em 1860 (SOUSA, 1955, p. 334335). Ambas foram excluídas do livro, em 1901.

Esse é o primeiro ponto contra "Monte Alverne". Tudo indica que o critério do autor, já ao tempo da composição do livro, relegava a segundo plano as composições mais antigas. Ele vinha publicando versos em jornais desde 1854 (SOUSA, 1979, p. 17-20), e apenas composições posteriores a 1858 apareceram no livro. É justo pensar que, com o passar do tempo, esse critério - de desconsiderar as produções mais antigas - mais se apurasse e mais se afirmasse.

Circunstância agravante, em relação a esse poema, foi a reação da crítica. Desde as primeiras avaliações, a principal qualidade reconhecida 
por todos em Crisálidas foi assim expressa por F. T. Leitão (1866, p. 382): "Os trabalhos encerrados no livro sujeito aos dizeres do público são trinta e quatro [o crítico contou cada uma das seis partes de Versos a Corina como um "trabalho"] em sua quase totalidade líricos. O lirismo é o lado mais dileto de M. de Assis, e é das produções desse gênero que lhe têm vindo as melhores palmas."

Sendo o lirismo a característica fundamental do livro, e sendo a vocação para ele [o lirismo] o que a crítica lhe reconhecia como a característica mais evidente, é justo pensar que, mais tarde, o poeta se resolvesse a retirar do livro os poemas que não diziam respeito, estritamente, à esfera da subjetividade, ou, em outras palavras, os poemas que não fossem puramente líricos - em que pese a conservação, no livro, dos poemas "Polônia" e "México".

Outra possibilidade é a de o autor não reconhecer mais em si, na idade madura, certos elementos de sua subjetividade quando jovem, como a crença religiosa, por exemplo - o que será ponderado adiante.

Esse mesmo crítico assim se expressou sobre o poema: “"Mont'Alverne' encerra duas estrofes lindíssimas e proporcionais ao elevado do assunto. Infelizmente a par da pequenhez do conto encontramos um ou outro verso menos regular, um ou outro descuido" (LEITÃO, 1866, p. 383). É difícil saber hoje as estrofes que o crítico tinha por "lindíssimas", mas o fato é que a opinião negativa se sobrepõe a esse elogio. O crítico não via apenas desproporção entre a altura, ou grandeza, do assunto e a pequena extensão do poema - proporção que Machado de Assis como crítico sempre levava em consideração em suas avaliações críticas de poesia; ele viu também, embora não os apontasse diretamente, "um ou outro verso menos regular, um ou outro descuido".

Outro crítico, Luís José Pereira da Silva (1864, p. 242-243), escreveu: "Na escolha dos assuntos, apartou-se o Sr. Machado de Assis de sua natureza, entoando louvores a Mont'Alverne. Apesar de algumas estrofes belíssimas, pensamos que esta poesia não está na altura do assunto." Novamente são reconhecidas a vocação do poeta para o lirismo puro ("apartou-se o Sr. Machado de Assis de sua natureza") e a falta de proporção entre o assunto e o poema concretamente realizado.

Outro crítico ainda, M. A. Major (1864, p. 213), escreveu, sobre o poema: “... o canto foi diminuto para o assunto: ele requer mais força e majestade, e na particularização de uma glória maravilhosa só a poesia veemente e arrojada pode cabalmente preencher sua missão ingente." Es- 
sas queixas de falta de adequação sugerem que o esperado, no caso, eram metáforas mais arrojadas, hipérboles mais robustas, mais pompa enfim.

Machado de Assis, vinte anos depois, no ensaio "A nova geração", emitiu opinião francamente negativa justamente contra essa tendência na poesia condoreira (ASSIS, 1955a, p. 190); é de supor-se que a recusa à grandiloquência só tenha aumentado com o passar do tempo, e que, em 1901, já na maturidade, o poeta considerasse o fenômeno poético com mais serenidade.

A desproporção assinalada entre o assunto e o poema, entre a pouca elevação dos versos e a altura reclamada pelo tema, demonstra claramente que Monte Alverne foi um mito para aquela geração; todos reconheciam nele a excepcionalidade do talento de orador.

Frei Francisco de Monte Alverne, no século Francisco José de Carvalho, nascera em 1784, tornara-se franciscano em 1802 e conquistara fama como orador sacro. Em 1836 ficou cego, retirando-se dos púlpitos. Entretanto, em 19 de outubro de 1854, acedendo a convite do imperador, pregou o sermão que se destacaria no conjunto de sua obra - o Segundo panegírico de S. Pedro de Alcântara. (BLAKE, 1970, v. 3, p. 49-52).

Por essa época, tinha Machado de Assis 15 anos de idade, acabava de publicar, no dia 3 do mesmo mês, sua primeira poesia. José de Alencar, aos 25 anos, publicava as crônicas de Ao correr da pena no Correio Mercantil. Na crônica de 22 de outubro daquele ano, assim narrou ele o início do sermão:

Cessaram de todo as orações. Recresce a expectação e a ansiedade; mas cada um se retrai na mudez da concentração. Os gestos se reprimem, contêm-se as respirações anelantes. O silêncio vai descendo frouxa e lentamente do alto das abóbadas ao longo das paredes, e sepulta de repente o vasto âmbito do templo.

Chegou o momento. Todos os olhos estão fixos, todos os espíritos atentos.

No vão escuro da estreita arcada do púlpito assomou um vulto. É um velho cego, quebrado pelos anos, vergado pela idade. Nessa bela cabeça quase calva e encanecida pousa-lhe o espírito da religião sob a tríplice auréola da inteligência, da velhice e da desgraça.

$[\ldots]$ 
Ajoelhou. Curvou a cabeça sobre a borda do púlpito, e revolvendo as cinzas de um longo passado, murmurou uma oração, um mistério entre ele e Deus.

Que há em tudo isto que desse causa a tamanha expectação? Não se encontra a cada momento um velho, a quem o claustro sequestrou do mundo, a quem a cegueira privou da luz dos olhos? Não há aí tanta inteligência que um voto encerra numa célula, e que a desgraça sepulta nas trevas?

É verdade. Mas deixai que termine aquela rápida oração; esperai um momento... um segundo... ei-lo!

$\mathrm{O}$ velho ergueu a cabeça; alçou o porte; a sua fisionomia animou-se. $\mathrm{O}$ braço descarnado abriu um gesto incisivo; os lábios, quebrantando o silêncio de vinte anos, lançaram aquela palavra sonora, que encheu o recinto, e que foi acordar os ecos adormecidos de outros tempos.

Fr. Francisco de Monte Alverne pregava! (ALENCAR, 1854, p. 1)

Não há informação segura de que Machado de Assis tenha assistido à pregação desse sermão, embora, por aquele tempo, fosse amigo do padre Silveira Sarmento, a quem dedicou o poema sobre o grande orador (ASSIS, 1864, p. 111-114 e p. 171), e, dizem, sacristão na igreja da Lampadosa. Embora não exista comprovação documental de que ele tenha sido sacristão, há diversos depoimentos que tornam crível a hipótese (PEREIRA, 1988, p. 45-59).

Lúcia Miguel Pereira (1988) e Raimundo Magalhães Júnior (1981) não dão notícia de Machado de Assis ter estado presente ao sermão de Monte Alverne; e Jean-Michel Massa (1971, p. 182) afirma: "Nenhuma alusão [em textos do autor] deixa perceber que Machado de Assis assistiu aos sermões do franciscano." Massa (1971, p. 182) diz ainda que Monte Alverne fora convidado à pregação pelo Imperador em 1854, mas que ele "subiu ao púlpito em julho de 1856". A citada crônica de José de Alencar, entretanto, foi publicada em 1854.

Alfredo Pujol (2007, p. 4), embora não afirme positivamente que ele tenha assistido ao sermão, dá a entender que sim, pois alega que a religiosidade do jovem escritor foi exaltada pelo "célebre sermão de S. Pedro de Alcântara, que a instâncias do imperador pregou na Capela Imperial, em 1854, o sábio franciscano Monte Alverne." Álvaro Guerra (s.d., p. 9-10), na trilha de Alfredo Pujol, e na tentativa de explicar-lhe a religiosi- 
dade dos primeiros anos, afirma que o célebre sermão teria deixado nele uma impressão profunda. Esse autor, porém, não cita fontes, e faz sua afirmativa num livro destinado ao público infantil.

O fato é que Machado de Assis, quando ainda ensaiava seus primeiros passos na arte da prosa, escreveu sobre ele:

Mont'Alverne é um nome de uma extensão infinita, que desperta em nossos corações as sensações mais profundas, o entusiasmo mais férvido, porque Mont'Alverne quer dizer uma glória do Brasil, um primor do púlpito, um Bossuet nascido nas plagas brasileiras e inspirado na solidão do claustro! (ASSIS, 2008, v. 3, p. 995).

Deve Machado de Assis ter reconhecido que a sua maneira, a entonação de sua tuba, seu temperamento, enfim, não se ajustavam ao tema. Quando, em 1879, já mais maduro, avaliou os poetas de seu tempo, no ensaio "A nova geração", entendeu que o estreante Alberto de Oliveira "é um poeta doméstico, delicado, fino"; repreendeu-lhe a intenção de seguir os passos de outros poetas de sua geração, de querer cantar "os gigantes": "O verso do Sr. Alberto de Oliveira tem a estatura média, o tom brando, o colorido azul, enfim um ar gracioso e não épico. Os gigantes querem o tom másculo." Machado insistiu, dizendo que ele deveria apurar "as suas qualidades" - "adquira-as novas, se puder, mas não opostas à índole de seu talento; numa palavra: afirme-se" (ASSIS, 1955a, p. 218 e 221).

Quando lhe prefaciou as Meridionais (1884), recordou-se da crítica que fizera ao poeta cinco anos antes, reconheceu que ele seguira seus conselhos:

Não trago essa reminiscência crítica (e deixo de transcrever as expressões de merecido louvor), senão para explicar, em primeiro lugar, a escolha que o poeta fez da minha pessoa para abrir este outro livro; e, em segundo lugar, para dizer que a exortação final da minha crítica tem aqui uma brilhante resposta, e que o conselho não foi desprezado, porque o poeta deixou-se estar efetivamente no castelo, não com a filha, mas com as filhas do castelão, o que é ainda mais do que eu the pedia naquele tempo. (ASSIS, 1955a, p. 318-319)

É de perguntar-se se não sucedeu a Machado de Assis o fenômeno que ele reconheceu em Alberto de Oliveira: o de não ser dado a grandes alturas o seu verso. Empregando palavras de um crítico do tempo (provavelmente Ferreira de Araújo) em resenha de Americanas, sua inspiração, "se voa muito bem, não voa muito alto" (L., 1876, p. 1). O mais provável é que o poeta tenha reconhecido em si essa característica. Se isso acon- 
teceu, o golpe de misericórdia estava dado no poema "Monte Alverne".

Machado de Assis, levado pelas circunstâncias de sua vida, fez muitos poemas de ocasião, às vezes mesmo atendendo a encomendas, pois se podem incluir nesta categoria boa parte dos versos escritos em álbuns. Na comédia Os deuses de casaca, Apolo se queixa do ábum, um “inimigo sério" dos poetas (ASSIS, 1962, p. 208-209). A musa cívica do poeta muitas vezes se manifestou, celebrando acontecimentos do momento.

Em "Monte Alverne", a intenção evidente era a de celebrar a morte do orador. Um outro poema seu, celebrando a inauguração da estátua de José Bonifácio, publicado em Americanas, foi considerado, à época, por seu amigo Salvador de Mendonça (1876, p. 238), “a menos inspirada produção" do livro. E outro poema, também de Americanas, composto por ocasião da morte de Gonçalves Dias, teve sua "parte cívica" drasticamente amputada do poema por Manuel Bandeira (1937, p. 223-224), que o transcreveu apenas em parte, em sua Antologia dos poetas brasileiros da fase romântica, com outro título "Nênia da virgem indiana à morte de Gonçalves Dias". Como se vê, tanto a crítica do tempo como a crítica posterior apontaram esse "ponto fraco" na obra poética de Machado de Assis, ponto de que ele, ao que tudo indica, pelo menos parcialmente, se deu conta.

Outra circunstância a ser assinalada, em relação ao poema "Monte Alverne", como possível razão de sua exclusão do livro, consiste no fato de ele, na primeira edição, ter sido dedicado a "Ao Padre-Mestre A. J. da Silveira Sarmento" (ASSIS, 1864, p. 111).

Nenhum poema com dedicatória na primeira edição permaneceu no livro na edição de 1901 . Nem mesmo a dedicatória do volume - “ $A$ Memória / de / Francisco José de Assis / e / Maria Leopoldina Machado de Assis / Meus pais." - foi mantida na obra.

Em nota ao final de Crisálidas, falou o poeta da dedicatória do poema: "Não há nesta poesia só um tributo de amizade e de admiração [a Silveira Sarmento]: há igualmente a lembrança de um ano de minha vida. O padre-mestre, alguns anos mais velho do que eu, fazia-se nesse tempo um modesto preceptor e um agradável companheiro" (ASSIS, 1864, p. 171). O ano a que se refere o autor é, muito provavelmente, o de 1858 , em que compôs e publicou duas poesias dedicadas a Silveira Sarmento, e em que já era "colaborador da Marmota, e tipógrafo da Imprensa Nacional” (PEREIRA, 1988, p. 56).

$\mathrm{O}$ único poema com referência clara e inequívoca à circunstância 
biográfica que permaneceu nas Poesias completas foi "Elegia". O poema foi composto por ocasião da morte da atriz Ludovina Moutinho, filha da também atriz Gabriela da Cunha, e tinha o título de "Ludovina Moutinho" na edição de 1864 - título que foi alterado para "Elegia", na edição de 1901, ficando eliminada a referência à pessoa celebrada no canto fúnebre (ASSIS, 1864, p. 59-63; ASSIS, 1901, p. 22-25). O poeta parecia disposto a afastar sua obra de sua biografia.

É uma reconhecida característica do escritor Machado de Assis a dissimulação, em sua criação literária, das circunstâncias que o limitavam: sua origem humilde, a cor de sua pele, sua gagueira, sua doença incurável. Tal característica é praticamente uma constante na crítica machadiana, que só foi em parte abandonada a partir da segunda metade do século XX - abandonada pela adesão dos críticos aos enfoques que privilegiam a obra, enfoque que certamente agradaria ao poeta, já que, como se procura demonstrar neste artigo, ele se esforçou por eliminar da obra referências às circunstâncias concretas de sua vida.

Em estudo em que compara os diferentes efeitos das condições existenciais sobre os temperamentos de Lima Barreto e de Machado de Assis, escreveu Sérgio Buarque de Holanda:

Enquanto os escritos de Lima Barreto foram, todos eles, uma confissão mal disfarçada, [...], os de Machado foram antes uma evasão e um refúgio. $\mathrm{O}$ mesmo tema que para o primeiro representa obsessivo tormento e tormento que não pode calar, este o dissimula por todos os meios ao seu alcance. E afinal triunfa na realização literária, onde a dissimulação cuidadosamente cultivada irá expandir-se até o ponto de se converter no ingrediente necessário de uma arte feita de vigilância, de reserva e de tato. Machado de Assis aristocratizou-se por esforço próprio e da disciplina que para isso se impôs, ficou em seu temperamento e em sua obra uma vertente inumana, que deveria desagradar a espíritos menos capazes de contenção. (HOLANDA, 1958, p.12)

A eliminação da referência ao vínculo biográfico com o padre Sarmento, e também com a religião católica, pode muito bem ser compreendida como parte desse esforço de depuração da obra literária de que falou Sérgio Buarque de Holanda.

111

Há ainda, em "Monte Alverne", os aspectos negativos estritamente técnicos, que poderiam somar-se ao conjunto das explicações já apresen- 
tadas para justificar sua exclusão das Poesias completas. A crítica havia reparado não somente na desproporção entre o assunto e a realização poética, mas também apontara "um ou outro descuido" - o que muito há de ter desagradado ao poeta, cultor que era da correção linguística, da boa técnica, da forma perfeita.

O poema se compõe de doze estrofes de cinco versos, em que o primeiro, o terceiro e o quarto são decassílabos brancos, e o segundo e o quinto são hexassílabos que rimam entre si. As rimas, apenas um par em cada estrofe, são todas agudas.

Sendo Machado de Assis um seguidor da técnica do verso tal como a preconizava Antônio Feliciano de Castilho, e sendo a opinião desse autor que os versos agudos não condizem senão "com as ideias extravagantes, cômicas, brutescas ou satíricas” (CASTILHO, 1851, p. 24), há o poeta de ter sentido algum constrangimento, ao lhe apontarem, nos versos, alguns "senões".

Talvez tenha sentido, na idade madura, que valiam para seus versos palavras semelhantes às que ele dedicara aos versos portugueses de Antônio José de Araújo, em sua tradução da tragédia Cinna, de Corneille - tragédia levada ao palco no Rio de Janeiro, em dezembro de 1861, e à qual, em crônica semanal publicada em 29 do mesmo mês no Diário do Rio de Janeiro, fizera a seguinte restrição:

Pareceu-me, tanto quanto pude ouvir na primeira representação, um trabalho cuidado e feliz. E, bem que o emprego de versos agudos traga algumas vezes a desarmonia e o enfraquecimento à poesia, há trechos de um completo acabado, já na harmonia poética, já na fidelidade da tradução. (ASSIS, 1955b, p. 107)

Além disso, há ainda outros aspectos a serem considerados.

Se, para Machado de Assis (1955a, p. 324-325), como ele ditou ao poeta Enéas Galvão - numa metáfora em que equipara o verso ou o poema e seu assunto ou tema, respectivamente, a corpo e alma -, se é verdade que "toda alma precisa de um corpo" - isto é, toda ideia ou sentimento a ser expresso precisa da materialidade do verso -, e que, em poesia, "nem tudo deve ser corpo" - ou seja, não basta a versificação perfeita -, e, ainda, que "a perfeição, neste caso, é a harmonia das partes" - vale dizer, é a harmonia entre a ideia e a forma; se todo o rigor do crítico Machado de Assis se deve aplicar a sua própria produção de poeta, caberia examinar as três condições da boa poesia enunciadas por ele: os aspectos nocionais, as ideias; os aspectos formais, a técnica do 
verso; e a "harmonia entre as partes".

No tocante à harmonia entre as partes, a crítica contemporânea do poeta foi unânime em apontar o descompasso entre a altura da ambição, do assunto do poema, assim como a circunstância fúnebre, grave, da ocasião, e a realização acanhada do poema. Para esse julgamento, estavam os contemporâneos mais aparelhados do que nós; acatemos-lhes, portanto, as ideias, a avaliação, a condenação. Monte Alverne, o pregador, não tem para nós, hoje, o significado que tinha naquele contexto, não tem mais o prestígio que teve; muito raramente é lido ou citado, e só por especialistas.

No plano das ideias, nem sempre o poeta foi feliz em suas escolhas. Na quinta estrofe, no primeiro e segundo versos, lê-se: “... A argila se alquebrava / Num áspero crisol” (ASSIS, 1976, p. 207) - o que é uma imagem de gosto duvidoso, um tanto infeliz, em que a "argila", lembrando os pés da estátua no sonho de Nabucodonosor, significa o corpo do orador - e como poderia a argila "alquebrar-se"? -; e o "áspero crisol" está, aparentemente, na falta de outro entendimento (que não nos ocorre), por sua plateia ou pela circunstância da pregação.

Na nona estrofe ocorrem estes versos -

Não todo à essa foi teu vulto olímpico;

Como deixa o cometa uma áurea cauda,

A lembrança ficou! (ASSIS, 1976, p. 207)

- em que a comparação da lembrança que ficou do morto com a cauda de um cometa não é lá muito elogiosa, pois as caudas passam, como os cometas.

Na décima estrofe diz o poeta:

O que hoje resta era a terrena púrpura

Daquele gênio-rei;

A alma voou ao seio do infinito

Voltou à pátria das divinas glórias

O apóstolo da lei. (ASSIS, 1976, p.207)

Isto de "Voltou à pátria das divinas glórias" é um tanto enigmático, não faz sentido se se levar em conta a doutrina católica. Como poderia $\mathrm{o}$ morto ter estado antes no céu? - há de se perguntar o leitor. Além disso, dessa particular incoerência, o próprio sistema de crenças que dá suporte 
aos versos pode ter contribuído para a exclusão do poema. O aspecto religioso, por si só, deve também ser tomado em consideração, pois o poema expressa uma fé que o poeta já não possuía ao final da vida.

Raimundo Magalhães Júnior (1981, v. 4, p. 360), biógrafo do poeta, informa sobre seus últimos dias e momentos de vida, em 1908: "Não quis que chamassem padre, para assisti-lo nos últimos momentos e dar-lhe a extrema-unção. Achou que seria hipocrisia. Perdera a fé da mocidade, dos tempos em que escrevia poesias cheias de sentimento religioso." Mais um provável motivo para a supressão do poema. Outras poesias de assunto ainda mais estritamente religioso foram também suprimidas do livro.

Quanto à forma externa e à técnica do verso, como no plano das ideias, só se pode especular sobre as restrições feitas pelos críticos do poeta. Um verso da primeira estrofe, entretanto, parece ser um inegável descuido:

$$
\begin{aligned}
& \text { Morreu! - Assim baqueia a estátua erguida } \\
& \text { No alto do pedestal; } \\
& \text { Assim o cedro das florestas virgens } \\
& \text { Cai pelo embate do corcel dos ventos }
\end{aligned}
$$

Na hora do temporal. (ASSIS, 1976, p. 206)

Essa estrofe é repetida no final, com a diferença de encerrar o poema por ponto de exclamação. A ideia não apresenta problemas que se possam questionar - tem seu quê de retórica, o que era comum no tempo e no autor. O último verso, entretanto, tem sete sílabas; para ser hexassílabo e fazer jogo rítmico com os decassílabos, de que é o quebrado, seria necessária a apócope do "a" de "Na", devendo-se ler "N'ora do temporal - pois o encontro vocálico "a - o", com o "o" tônico, jamais daria um ditongo (OITICICA, 1955, p. 62-64; ELIA, 1971, p. 115-122). O resultado é um cacófato desconfortável e inaceitável no contexto: "nora". A única outra possível solução aparente seria a síncope do "o" de temporal, o que resultaria na cacofônica e desconfortável pronúncia “temp'ral”.

Tais soluções - a apócope ou a síncope - fazem parte dos modos de alterar o número de sílabas de um verso, e receberam, da parte de Antônio Feliciano de Castilho (1851, p. 12-13), a seguinte "Advertência restritiva": "No usar de qualquer das seis [aférese, prótese, síncope, epêntese, apócope e paragoge] figuras sobreditas deve haver suma cautela, pois que o nome de figura nestes casos é máscara lustrosa, com que se pretende encobrir um defeito muito real." Como no caso do uso de rimas agudas 
já apontado, muito provavelmente essas palavras de repreensão ecoavam tormentosamente no ouvido do poeta.

Além das rimas agudas já assinaladas e do problema métrico presente no último verso da primeira estrofe, devem ser apontadas algumas repetições em sílabas métricas subsequentes, que devem ser distintamente pronunciadas, como ocorre, por exemplo no quarto verso da segunda estrofe - "Amanhã ante as pálidas ruínas"; e uma ou outra sinalefa que pode confundir o sentido das palavras, como ocorre no segundo verso da sétima estrofe - "Era como um fanal" -, que deve ser pronunciado "Era com' um fanal". Tais são outros possíveis descuidos mencionados, mas não exatamente indigitados pelos críticos. Não são propriamente "erros", e ocorrências semelhantes existem nos poemas que o poeta manteve nas Poesias completas.

Ainda um outro verso tem estrutura prosodicamente ambígua: "Era uma geração, um século inteiro," - nele, ou o "um" se absorve no ditongo final de "geração" e o verso resulta defeituoso do ponto de vista nocional, porque o artigo "um" é essencial ao sentido do segundo hemistíquio e, por isso, deve ser distintamente pronunciado; ou se há de dizer "séc'lo", com síncope, o que afastaria o verso do modo brasileiro de falar e o aproximaria do falar português. Deve-se reconhecer, no entanto, que a síncope da penúltima vogal, em palavras proparoxítonas, é relativamente comum no português brasileiro. Nesse caso, portanto, a síncope não parece ser grande problema, embora o poeta não a tenha indicado no verso, podendo tê-lo feito: a pronúncia sincopada não se afasta tanto da pronúncia normal brasileira. Além disso, o recurso à prosódia lusitana era amplamente usado na tradição poética local, incluindo-se aí, especialmente, os poetas românticos.

No poema "Monte Alverne" convergem, pois, as principais possíveis razões que o poeta teria tido para rejeitar na idade madura alguns dos poemas escritos no passado distante: o fato de o poema estar vinculado à sua circunstância biográfica, pelo tema e pela dedicatória; o fato de estar vinculado a um sentimento religioso, que o poeta já não tinha ao final da vida; e o fato de o poema apresentar alguns senões, tanto no plano das ideias como na técnica da versificação. 


\section{MACHADO DE ASSIS AND MONTE ALVERNE}

\section{ABSTRACT}

This paper analyzes the poem "Monte Alverne", by Machado de Assis, in the search for possible reasons to its exclusion from the Poesias completas [Complete poetry] organized by the poet himself in 1901. In the search to explain the poem's exclusion, the relations it holds with the context in which it was produced were examined, as well as the images the poet used in it and the technical aspects of its composition.

KEY WORDS: Brazilian poetry; Machado de Assis; Monte Averne.

\section{REFERÊNCIAS}

ALENCAR, José de. Ao correr da pena. Correio Mercantil, Rio de Janeiro, p. 1, 22 out. 1854. Fac-símile disponível em:

$<$ http://memoria.bn.br/DocReader/docreader.aspx?bib=217280\&pasta=ano $\% 20$ 185\&pesq=> Acesso em: 28 abr. 2016.

ASSIS, J. M. Machado de. Mont'Alverne. Jornal do Comércio, Rio de Janeiro, 6 dez. 1858. Suplemento, p. 6. Fac-símile disponível em:

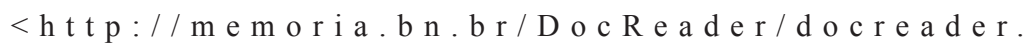
aspx?bib=364568_04\&pasta=ano\%20185\&pesq=> Acesso em: 28 abr. 2016.

ASSIS, Machado de. Crisálidas. Rio de Janeiro: B. L. Garnier, 1864. Fac-símile disponível em: <http://www.brasiliana.usp.br/search?\&fq=dc.contributor.author $\% 3$ AAssis $\% 2 \mathrm{C} \% 5 \mathrm{C}+\mathrm{Machado} \% 5 \mathrm{C}+\mathrm{de} \% 2 \mathrm{C} \% 5 \mathrm{C}+1839 \% 5 \mathrm{C}-1908>$ Acesso em: 28 abr. 2016.

ASSIS, Machado de. Poesias completas. Rio de Janeiro: H. Garnier, 1901. Fac-símile disponível em: 
$<$ http://www.brasiliana.usp.br/search?\&fq=dc.contributor.author\%3AAssis $\% 2 \mathrm{C}$ $\% 5 \mathrm{C}+$ Machado\%5C+de\%2C\%5C+1839\%5C-1908> Acesso em: 28 abr. 2016.

ASSIS, Machado de. Crítica literária. Rio de Janeiro: W. M. Jackson, 1955a.

ASSIS, Machado de. Crônicas, $1^{\circ}$ volume (1859-1863). Rio de Janeiro: W. M. Jackson, 1955b.

ASSIS, Machado de. Ressurreição. Rio de Janeiro: W. M. Jackson, 1955c.

ASSIS, Machado de. Teatro. São Paulo: Mérito, 1962.

ASSIS, Machado de. Poesias completas. Ed. crítica pela Comissão Machado de Assis. Rio de Janeiro: Civilização Brasileira, 1976.

ASSIS, Machado de. Obra completa em quatro volumes. Rio de Janeiro: Nova Aguilar, 2008.

ASSIS, Machado de. A poesia completa. Org. Rutzkaya Queiroz dos Reis. São Paulo: Nankin, 2009.

BANDEIRA, Manuel. Antologia dos poetas brasileiros da fase romântica. Rio de Janeiro: Imprensa Nacional, 1937.

BLAKE, Sacramento. Dicionário bibliográfico brasileiro. Ed. fac-similar. Rio de Janeiro: Conselho Federal de Cultura, 1970. 7v.

CASTILHO, A. F. de. Tratado de metrificação portuguesa. Lisboa: Imprensa Nacional, 1851. Fac-símile disponível em:

$<$ https://books.google.com.br/books/about/Tratado_de_ metrifica\%C3\%A7\%C3\%A3o_portugueza_par.html?id=f2EVAAAAYAAJ > Acesso em: 28 abr. 2016.

COZER, Raquel. Poema desconhecido que Machado de Assis escreveu aos 17 anos é descoberto. Folha de S.Paulo, São Paulo, 14 mar. 2015. Disponível em: $<$ http://www1.folha.uol.com.br/ilustrada/2015/03/1602428-poema-desconhecido-que-machado-de-assis-escreveu-aos-17-anos-e-descoberto.shtml $>$ Acesso em: 28 abr. 2016.

ELIA, Hamilton. Fenômenos fonéticos ocorrentes no verso. In: II Congresso brasileiro de língua e literatura (de 6 a 17 de julho de 1970). Rio de Janeiro: Gernasa e Artes Gráficas, 1971.p. 111-122.

GUERRA, Álvaro. Machado de Assis (Sua vida e suas obras). 3. ed. São Paulo: Melhoramentos, s.d. [Galeria de grandes homens, n. 11.]

HOLANDA, Sérgio Buarque de. Prefácio. In: BARRETO, Lima. Clara dos Anjos. São Paulo: Brasiliense, 1956.

L. [Ferreira de Araújo] Crônica bibliográfica: Americanas, por Machado d'Assis. Gazeta de Notícias, Rio de Janeiro, p. 1, 11 jan. 1876. Fac-símile disponível em: 
< h t t p : / / m e moria.bn.br/D o c R e a d e r / d o c r e a d e r. aspx?bib=103730_01\&pasta=ano\%20187\&pesq=> Acesso em: 27 abr. 2016. Texto transcrito integralmente em ASSIS, 2009, e parcialmente em MACHADO, 2003.

LEITÃO, F. T. Crisálidas - volume de poesias de Machado de Assis. Revista Mensal da Sociedade Ensaios Literários, Rio de Janeiro, $3^{\circ}$ ano, n. 10, p. 378384, 05 jun. 1866. Fac-símile disponível em:

$<$ http://memoria.bn.br/DocReader/docreader.aspx?bib=338966\&pasta=ano $\% 20$ 186\&pesq=> Acesso em: 27 abr. 2016. Texto reproduzido em ASSIS, 2009, e em MACHADO, 2003.

MACHADO, Ubiratan. Org. Machado de Assis: Roteiro de consagração (Crítica em vida do autor). Rio de Janeiro: EdUERJ, 2003.

MAGALHÃES JÚNIOR, R. Vida e obra de Machado de Assis. Rio de Janeiro: Civilização Brasileira, 1981. 4v.

MAJOR, M. A. Crisálidas (Machado de Assis). Revista Mensal da Sociedade Ensaios Literários, Rio de Janeiro, $2^{\circ}$ ano, n. 6, p. 207-216, $1^{\circ}$ nov. 1864. Fac-símile disponível em: <http://memoria.bn.br/DocReader/docreader. aspx?bib=338966\&pasta $=$ ano\%20186\&pesq=> Acesso em: 27 abr. 2016. Texto transcrito em ASSIS, 2009, e parcialmente em MACHADO, 2003.

MASSA, Jean-Michel. A juventude de Machado de Assis - 1839-1870: Ensaio de biografia intelectual. Rio de Janeiro: Civilização Brasileira, 1971.

[MENDONÇA, Salvador de.] Literatura. Americanas. O novo mundo, New York, v. VI, n. 71, p. 238, ago. 1876. Fac-símile disponível em:

$<$ http://memoria.bn.br/DocReader/docreader.aspx?bib=122815\&pasta=ano $\% 20$ 187\&pesq=> Acesso em: 27 abr. 2016. Texto transcrito integralmente em ASSIS, 2009, e parcialmente em MACHADO, 2003.

MORAES, Eugênio Vinci de. A tijuca e o pântano. A Divina Comédia na obra de Machado de Assis entre 1870 e 1881. São Paulo: Universidade de São Paulo, 2007. [Tese de doutorado.] Disponível em: <http://www.teses.usp.br/teses/disponiveis/8/8149/tde-13022008-105611/pt-br.php> Acesso em: 28 abr. 2016.

OITICICA, José. Roteiros em fonética fisiológica, técnica do verso e dição. Coligidos e revistos por Almir Câmara de Mato Peixoto. Rio de Janeiro: Simões, 1955.

PEREIRA, Lúcia Miguel. Machado de Assis (Estudo crítico e biográfico). 6. ed. rev. Belo Horizonte: Itatiaia, 1988.

PUJOL, Alfredo. Machado de Assis: Curso literário em sete conferências na Sociedade de Cultura Artística de São Paulo. 2. ed. Rio de Janeiro: Academia Bra- 
sileira de Letras, 2007.

SILVA, Luís José Pereira da. Crônica. Revista Mensal da Sociedade Ensaios Literários, Rio de Janeiro, $2^{\circ}$ ano, n. 6, p. 237-246, $1^{\circ}$ nov. 1864. Fac-símile disponível em:

$<$ http://memoria.bn.br/DocReader/docreader.aspx?bib=338966\&pasta $=$ ano $\% 20$ 186\&pesq $=>$ Acesso em: 27 abr. 2016. Texto parcialmente transcrito em ASSIS, 2009, e em MACHADO, 2003.

SOUSA, J. Galante de. Bibliografia de Machado de Assis. Rio de Janeiro: Instituto Nacional do Livro, 1955.

SOUSA, J. Galante de. Os primeiros versos de Machado de Assis. In:

Machado de Assis e outros escritos. Rio de Janeiro: Cátedra, 1979. p. 17-20.

Recebido em: 30 de abril de 2016

Aceito em: 19 de outubro de 2016 